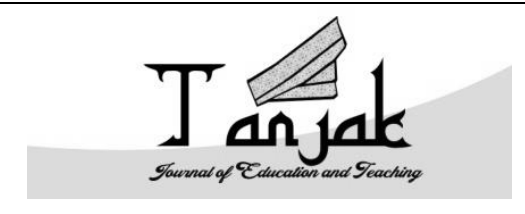

Tanjak: Journal of Education and Teaching

ISSN 2716-4098 (P) 2720-8966 (O)

Volume 1 Nomor 2, 2020

\title{
ANALISIS RESPON MAHASISWA TERHADAP PEMBELAJARAN ONLINE DI STAIN SULTAN ABDURRAHMAN KEPRI
}

\author{
Syukri Ernayati Nurintan Sahri Sinaga \\ STAIN Sultan Abdurrahman Kepri, syukri_ernayati@stainkepri.ac.id
}

DOI: https://doi.org/10.35961/tanjak.v1i2.151

\begin{abstract}
Abstrak
Pada masa pandemi Covid-19, solusi alternatif pembelajaran lebih banyak menggunakan online. Sehingga mau tidak mau, dosen maupun mahasiswa harus melaksanakan perkuliahan secara online. Disadari benar bahwa melaksanakan pembelajaran online tidak mudah dilakukan mengingat pembelajaran online merupakan hal baru dalam dunia pendidikan saat ini. Meskipun demikian, STAIN Sultan Abdurrahman Kepri tetap melakukan pembelajaran online dalam rangka pelaksanaan tridharma perguruan tinggi berupa pendidikan dan pengajaran. Untuk melihat bagaimana respon mahasiswa terhadap pembelajaran online yang dilaksanakan di STAIN Sultan Abdurrahman Kepri dilakukanlah penelitian ini. Adapun metode yang digunakan dalam penelitian ini adalah analisis deskriptif dengan pendekatan kuantitatif. Hasil yang diperoleh diketahui bahwa pelaksanaan pembelajaran online masih belum maksimal karena ternyata banyak mahasiswa lebih menyukai perkuliahan yang dilakukan secara langsung. Kendati demikian, melalui penggunaan berbagai aplikasi dalam pelaksanaan pembelajaran online setidaknya telah membantu mahasiswa dalam mengikuti perkuliahan dan memahami materi pembelajaran. Penelitian ini diharapkan dapat menjadi terobosan baru bagi STAIN Sultan Abdurrahman Kepri dalam melaksanakan pembelajaran online sehingga baik dosen maupun mahasiswa keduanya bisa sama-sama mengikuti proses kegiatan belajar mengajar dengan baik tentunya dengan meminimalisir kendala-kendala yang dihadapi mahasiswa.
\end{abstract}

Kata kunci: analisis respon ; pembelajaran online

Tanjak: Jounal of Education and Teaching, Vol. 1, No. 2, 2020 


\begin{abstract}
At the Covid-19 pandemic, alternative solutions are using online. So inevitably, lecturers and students should conduct lectures online. It is realized that implementing online learning is not easy considering that online learning is new in the world of education today. However, STAIN Sultan Abdurrahman Kepri continues to conduct online learning in the form of education and teaching Tridharma University. To see how students responses to online learning conducted in STAIN Sultan Abdurrahman Kepri did this research. The method used in this study is a descriptive analysis with a quantitative approach. The results are known that the implementation of online learning is still not maximal because it turns out that many students prefer the lectures that are done directly. Nevertheless, through the use of various applications in the implementation of online learning has at least helped students to follow lectures and understand the learning materials. This research is expected to be a new breakthrough for STAIN Sultan Abdurrahman Kepri in conducting online learning so that both lecturers and students can both follow the process of learning activities with good course by minimizing the constraints faced by students.
\end{abstract}

Keywords: response analysis ; online learning

\title{
Pendahuluan
}

Semenjak masa pandemi covid-19 pemerintah Indonesia telah memberlakukan social distancing (penjajaran sosial) dan melakukan lockdown pada semua daerah di Indonesia untuk mengurangi penyebaran virus Covid-19. Nadiem Makarim selaku Menteri Pendidikan dan Kebudayaan (Mendikbud) bahkan telah mewajibkan agar seluruh lembaga pendidikan dapat memberlakukan pembelajaran secara online dan bekerja dari rumah dalam upaya pencegahan dan penyebaran Covid-19. Kebijakan ini menjadi fenomena baru bagi lembaga pendidikan di Indonesia. Semua lembaga pendidikan tinggi termasuk Universitas sudah mulai menerapkan kegiatan pembelajaran dalam jaringan (daring) dan bekerja dari rumah sebagaimana yang juga telah dilakukan oleh STAIN Sultan Abdurrahman Kepri. Lembaga pendidikan tinggi kemudian mengalihkan pertemuan di kelas dengan pertemuan daring (online) ataupun tugas rumah guna menimalisir pertemuan antara seseorang dengan orang lainnya di dalam ruangan yang sama atau dalam jarak yang dekat sebagaimana himbauan pemerintah.

Pembelajaran dapat diartikan sebagai kegiatan yang dilakukan untuk menginisiasi, memfasilitasi dan meningkatkan intensitas dan kualitas belajar pada diri peserta didik. (Winataputra Udin S, 2007: 1). Adapun proses pembelajaran adalah upaya secara sistematis yang dilakukan guru untuk mewujudkan proses pembelajaran berjalan secara efektif dan efisien yang dimulai dari perencanaan, pelaksanaan dan evaluasi. (Zainal Aqib, 20013: 66).

Secara garis besar proses pembelajaran dipandang berhasil jika semua mahasiswa secara aktif mengikuti pembelajaran. Bila selama ini proses pembelajaran lebih banyak dilakukan di kelas maka kini proses pembelajaran dilakukan secara online. Sehingga dengan demikian dosen harus dapat melaksanakan kegiatan perkuliahan melalui pembelajaran online. Oleh karena itu, dosen haruslah memiliki kesiapan mental, dapat membagi waktu antara tugas dengan tanggungjawab, menguasai bahan pembelajaran, memahami kondisi mahasiswa, memaklumi keadaan yang dihadapi mahasiswa serta tetap semangat dalam bekerja walau harus mengajar secara online. (M. Sobry Sutikno, 2015: 19). 
Pembelajaran online dilakukan sebagai pengganti perkuliahan tatap muka. Pelaksanaan pembelajaran online merupakan hal baru bagi dosen maupun mahasiswa STAIN Sultan Abdurrahman Kepri terutama saat pandemi covid-19 terjadi, sehingga mekanisme pembelajaran online sedikit berbeda dari biasanya. Kegiatan pembelajaran dalam pembelajaran online tidak selalu mudah dilakukan, khususnya bagi mahasiswa STAIN Sultan Abdurrahman Kepri yang kebanyakan berasal dari pulaupulau terpencil di luar pulau Bintan seperti Pulau Lingga, Pulau Anambas, Pulau Mapur, Pulau Tambelan dan sebagainya. Kendati demikian, baik dosen maupun mahasiswa dapat memilih strategi komunikasi terbaik dalam berinteraksi dengan memanfaatkan berbagai aplikasi yang mendukung pembelajaran online. Strategi komunikasi yang dimaksud terkait dengan cara mahasiswa saat menghadiri kelas, mengikuti pembelajaran, menyampaikan materi, mengerjakan tugas hingga untuk mengikuti ujian sesuai dengan waktu yang telah ditetapkan dosen. Untuk melihat bagaimana respon mahasiswa terhadap pembelajaran online maka dilakukan penelitian ini.

\section{Metode Penelitian}

Jenis penelitian yang digunakan adalah penelitian kuantitatif. Metode pengumpulan data berupa menyebarkan angket kepada 50 orang mahasiswa STAIN Sultan Abdurrahman Kepri sebagai sampel yang terdiri dari tiga kelas yakni dua kelas dari prodi Manajemen Pendidikan Islam (MPI) dan satu kelas dari prodi Pendidikan Islam Anak Usia Dini (PIAUD). Setelah data terkumpul selanjutnya data dianalisis. Dalam menganalisa data tersebut penulis menggunakan analisis deskriptif kuantitatif yaitu sebuah analisa yang memberikan gambaran mengenai status subjek dalam kondisi tertentu. (Suharsimi Ari Kunto, 1990: 353). Setelah diperoleh hasil dari pengolahan data dan analisis data, penulis kemudian membuat kesimpulan terhadap masalah yang diteliti.

Adapun daftar pertanyaan dalam angket yang disebar kepada para mahasiswa berkaitan dengan pendapat dan respon mahasiswa terhadap pembelajaran online yang dilakukan di STAIN Sultan Abdurrahman Kepri terutama dalam memahami materi pelajaran, kendala yang dihadapi saat pembelajaran online, aplikasi yang mendukung pembelajaran online serta keefektifan pembelajaran online selama masa pandemi covid-19.

\section{Hasil dan Pembahasan}

Pembelajaran online merupakan proses belajar mengajar tanpa adanya pertemuan atau tatap muka secara langsung. Pembelajaran online yang dilakukan di STAIN Sultan Abdurrahman Kepri merupakan hal baru bagi mahasiswa khususnya ketika terjadi pandemi covid-19. Oleh karena itu, penelitian ini dilakukan untuk melihat bagaimana respon mahasiswa terhadap pembelajaran online di laksanakan di STAIN Sultan Abdurrahman Kepri.

Berdasarkan hasil penelitian, diketahui bahwa sebanyak 46 mahasiswa lebih menyukai pembelajaran di kelas di bandingkan pembelajaran online, karena bisa bertanya secara langsung dengan bahasa yang mudah dipahami sehingga proses belajar lebih efektif dan efisien. Namun 4 orang mahasiswa menyukai pembelajaran di kelas dan yang dilakukan secara online karena pembelajaran di kelas memberikan pengalaman belajar yang menyenangkan sedang pembelajaran online dipandang lebih santai dan dekat dengan anak khususnya bagi mahasiswa yang telah berkeluarga. 
Sebanyak 23 mahasiswa berpendapat bahwa pembelajaran online cukup efektif. Karena dapat membantu mahasiswa mengikuti materi perkuliahan meski tidak bisa dilakukan secara tatap muka. Keadaan yang terjadi juga memaksa dan menuntut berbagai pihak untuk dapat berfikir kritis dalam banyak keadaan. Pembelajaran online yang dilaksanakan menggunakan berbagai aplikasi terkadang sangat lancar, beberapa mahasiswa aktif dan dosen pengampu juga turut serta membimbing jalannya diskusi maupun menyampaikan materi. Sedangkan 27 mahasiswa berpendapat bahwa pembelajaran online yang dilakukan masih kurang efektif karena tidak semua mahasiswa menyimak proses pembelajaran online, sebagian ada yang sekedar mengisi absensi dan tidak peduli dengan penyampaian materi. Selain itu, proses kegiatan belajar mengajar akan jauh lebih mudah dipahami jika dilakukan secara langsung (tatap muka). Namun jika melihat keadaan pandemi saat ini, penerapan pembelajaran online yang dilakukan STAIN Sultan Abdurrahman Kepri merupakan tindakan yang tepat bagi mahasiswa dari pada mahasiswa hanya diliburkan maka tentu akan merugikan banyak pihak.

Untuk aplikasi yang mendukung pembelajaran online, sebanyak 30 mahasiswa memilih whatsapp sebagai aplikasi yang paling mendukung perkuliahan khususnya saat pengiriman tugas seperti makalah, lembar kerja, rekaman suara, video dan sebagainya. Hal ini dikarenakan kebanyakan mahasiswa sudah memiliki aplikasi tersebut. Fungsi dari aplikasi ini adalah untuk mengirimkan file serta menyampaikan materi yang dikirimkan oleh pemateri maupun dosen baik dalam bentuk tulisan maupun rekaman suara (voice note). Aplikasi whatsapp juga sangat menghemat kuota internet khususnya saat mengakses banyak data. Sehingga banyak mahasiswa lebih suka menggunakan aplikasi whatsapp sebagai media pelajaran dalam pembelajaran online.

Sebanyak 13 mahasiswa memilih zoom karena aplikasi tersebut memang diperuntukan untuk pertemuan tatap muka dan itu yang paling dekat dengan keadaan di kelas. Sehingga melalui aplikasi ini dapat membantu mahasiswa dalam memahami materi yang dijelaskan oleh dosen secara langsung. Melalui aplikasi video call di zoom dosen dapat mengetahui keberadaan mahasiswa apakah mahasiswa tersebut menyimak atau tidak serta memudahkan mahasiswa untuk melihat materi yang disampaikan oleh dosen.

Sebanyak 7 mahasiswa memilih google classroom karena dianggap memudahkan mahasiswa saat mengikuti pembelajaran online, aplikasi ini dipandang aman dan mudah digunakan, bisa dijadikan forum diskusi sederhana, mudah untuk melihat materi pelajaran dan komentar teman serta mekanisme pengambilan tugas dan penyerahan tugas lebih rapi dan terstruktur.

Umumnya, pelaksaaan pembelajaran online tidak selalu lancar dan mudah dilakukan. Berbagai kendala pun turut dialami dan dihadapi mahasiswa saat mengikuti pembelajaran online. Beberapa kendala tersebut antara lain:

1. Sinyal yang kurang mendukung khususnya di pulau-pulau kecil di kawasan kepulauan riau, hal ini terkadang membuat mahasiswa terlambat mengkuti pembelajaran online sesuai dengan waktu yang telah ditetapkan oleh dosen.

2. Tidak selalu tersedianya kuota internet untuk bisa digunakan dalam pembelajaran online. Misalnya ketika ingin mengunduh materi yang dikirim terkadang membutuhkan banyak kuota 
yang digunakan apalagi jika file yang diunduh berbentuk klip suara atau video biasanya akan memakan lebih banyak kuota internet.

3. Cuaca yang dapat berubah sewaktu-waktu dapat menganggu pembelajaran online misalnya mahasiswa kesulitan berkonsentrasi mengikuti materi pelajaran bila terjadi hujan deras, petir maupun badai.

4. Komunikasi yang kurang efektif antar individu yang memungkinkan terjadinya kesalahpahaman dalam memahami materi yang disampaikan oleh teman maupun yang dijelaskan oleh dosen.

5. Jaringan atau koneksi internet yang terkadang tidak selalu stabil sehingga menghambat kelancaran belajar online khususnya saat diskusi berlangsung.

6. Kekurangan waktu untuk diskusi, tanya jawab, sharing serta tidak bisa menyampaikan aspirasi secara bebas karena ada batasan waktu dalam pembelajaran online.

7. Kurangnya pemahaman mahasiswa terhadap penyampaian materi yang disampaikan tidak secara langsung (tatap muka).

8. Beberapa handphone yang dimiliki mahasiswa tidak mendukung untuk menggunakan aplikasi yang menggunakan banyak data.

Sungguhpun demikian, pembelajaran online di masa pandemi covid-19 menjadi solusi alternatif untuk STAIN Sultan Abdurrahman Kepri. Berbagai aplikasi yang digunakan dalam pembelajaran online seperti Zoom, Google Classrom dan WhatssApp memungkinkan para dosen untuk mengunggah materi mata kuliah guna memberikan materi pembelajaran, diskusi dan pemberian tugas. Aplikasi tersebut juga memberikan kemudahan dalam menyediakan materi yang dapat diakses oleh dosen dan mahasiswa. Meski pada awal diberlakukan pembelajaran online masih terdapat kendala dan kesulitan seperti tidak memadainya smartphone yang mendukung perkuliahan secara online, jaringan yang tidak stabil hingga aplikasi yang memakan banyak kuota tidak menjadi penghalang bagi mahasiswa STAIN Sultan Abdurrahman Kepri untuk mengikuti pelaksanaan pembelajaran online.

\section{Ragam Aplikasi dalam Pelaksanaan Pembelajaran online}

Kegiatan perkuliahan terdiri dari tiga komponen utama yaitu adanya dosen, adanya materi atau isi pelajaran dan adanya mahasiswa. Dosen memiliki peranan penting dalam memberikan pengajaran, sehingga kegiatan perkuliahan tidak akan berarti tanpa adanya dosen. Oleh karena itu, dosen menjadi komponen terpenting dalam keberlangsungan kegiatan perkuliahan. Pelaksanaan pengajaran merupakan salah satu tridarma perguruan tinggi, sehingga dalam keadaan bagaimanapun pengajaran harus tetap dilakukan meskipun harus secara online. Oleh karena itu, untuk mencapai hasil belajar yang optimal, sangat dianjurkan agar dosen dapat membiasakan diri menggunakan komunikasi banyak arah dengan memanfaatkan berbagai aplikasi dan media sosial yang digunakan dalam pembelajaran online. Ketiga hal tersebut baik dosen, materi atau isi pelajaran dan mahasiswa menjadi aspek terpenting dalam pembelajaran online. Sehingga pembelajaran online tidak akan terlaksana dengan baik jika salah satu hal tersebut tidak ada. Dalam mencapai interaksi belajar mengajar sudah tentu perlu adanya komunikasi yang baik antara dosen dengan mahasiswa. Beberapa kegiatan yang dapat dilakukan dosen saat pembelajaran online antara lain:

1. Membiasakan peserta didik membaca dan menulis melalui tugas-tugas tertentu yang bermakna. 
2. Memfasilitasi mahasiswa untuk belajar kelompok dengan memberi tugas (resitasi), diskusi dan lainnya untuk memunculkan ide dan gagasan baru yang dituangkan dalam bentuk lisan ataupun tertulis. (Novan Ardy Wiyani, 2013: 160-162).

3. Memberikan kesempatan peserta didik untuk berpikir, menganalisis, menyelesaikan masalah saat proses mengajar online berlangsung.

4. Memberikan materi yang mudah dipahami mahasiswa dan menjelaskannya dengan secara langsung melalui aplikasi yang mendukung.

Beberapa aplikasi yang dapat digunakan dalam pembelajaran online di STAIN Sultan Abdurrahman Kepri antara lain:

1. Zoom

Zoom merupakan aplikasi komunikasi yang pemakaiannya menggunakan video dan audio yang bisa digunakan untuk chatting, meeting, telepon, kelas online dan lain sebagainya secara langsung (live). Aplikasi tersebut dapat digunakan dalam berbagai perangkat seluler, desktop, hingga telepon dan sistem ruang. (Indotrading News, https://news.indotrading.com/mengenal-apa-itu-zoom-fitur-dan-carapemakaiannya, diakses 22 Juli 2020).

Zoom merupakan aplikasi dalam jaringan yang banyak digunakan oleh para pekerja saat Work From Home (WFH) diberlakukan. Dalam melaksanakan pembelajaran online beberapa dosen di STAIN Sultan Abdurrahman Kepri juga menggunakan aplikasi ini untuk menerangkan materi pada mahasiswa.

2. WhatsApp

WhatsApp adalah aplikasi pesan yang memungkinkan untuk bertukar pesan tanpa menggunakan pulsa, namun menggunakan paket data internet. Aplikasi WhatsApp menggunakan koneksi internet 3G, 4G atau WiFi untuk keperluan komunikasi data. (Wikipedia, https://id.wikipedia.org/wiki/WhatsApp, diakses 23 Juli 2020). Aplikasi ini menggunakan nomor telepon ponsel yang digunakan untuk berinteraksi dengan sesama pengguna WhatsApp yang lain dan dapat diunduh secara gratis di websitenya. Aplikasi ini memungkinkan pengguna untuk dapat saling berkomunikasi satu sama lain. Aplikasi ini menggunakan fitur push sehingga Anda dapat selalu memberitahukan pesan yang sedang diterima. Aplikasi WhatsApp membantu pengguna dalam melakukan obrolan dalam jaringan (daring), mengirim pesan teks maupun suara, berbagi file, mengirim foto, membuat status, melakukan video call dan lain-lain.

\section{Google Classroom}

Google Classroom atau dalam bahasa Indonesia berarti Google Kelas merupakan sebuah layanan web gratis yang dikembangkan oleh Google untuk kepentingan sekolah, yang berguna untuk mendukung kegiatan pembelajaran. Google Classroom bertujuan untuk memudahkan proses berbagi file antara dosen dengan mahasiswa. Cara yang dilakukan Google Classroom adalah dengan menggabungkan Google Drive untuk pembuatan dan pengiriman penugasan dan Google Docs, Sheets, Slides untuk penulisan, Gmail untuk komunikasi, dan Google Calendar untuk penjadwalan. Selain itu, mahasiswa dapat diundang untuk bergabung di kelas menggunakan kode pribadi yang ada di aplikasi. Setiap kelas dapat membuat folder secara terpisah di Drive masing-masing pengguna saat proses 
perkuliahan berlangsung, sehingga mahasiswa dapat mengirimkan materi maupun tugas dengan mudah untuk dapat diperiksa dan dinilai oleh dosen yang bersangkutan. Dosen dapat memantau kemajuan untuk setiap siswa, dan setelah dinilai, guru dapat kembali bekerja bersama dengan komentar Google Classroom juga dapat diakses di Handphone Android dan perangkat iOS, hal ini tentu akan memungkinkan pengguna dalam mengambil foto serta melampirkan tugas, berbagi file maupun mengakses informasi secara offline. Penggunaan Google Classroom dapat membantu dosen dalam menyederhanakan materi, membuat tugas, mendistribusikan file atau data dan menilai tugas mahasiswa dengan berbagi data atau dokumen tanpa harus membuang kertas. (Wikipedia, https://id.wikipedia.org/wiki/Google_Kelas, diakses 23 Juli 2020).

Melalui pembelajaran online, mahasiswa diajak untuk belajar secara mandiri baik dalam mencari materi maupun dalam mengerjakan tugas sendiri. Sungguhpun demikian, ketika pembelajaran online dilakukan ada banyak manfaat yang akan didapatkan mahasiswa yakni:

1. Mendapatkan pengalaman baru

2. Menjadi giat membaca

3. Waktu pembelajaran lebih singkat

4. Pembelajaran online dapat dilakukan di mana saja tanpa harus datang ke kampus.

5. Dapat mengkaji ulang pelajaran dengan merekam materi saat pembelajaran online berlangsung.

Untuk mendukung pemahaman dalam pembelajaran, mahasiswa diharapkan dapat membaca dan mengkaji berbagai media seperti e-book, jurnal, video, rekaman kuliah, kuis, forum diskusi, sesi tanya jawab langsung dan lain sebagainya. Melalui beragam aplikasi yang mendukung dalam pelaksanaan pembelajaran online dapat memudahkan mahasiswa dalam memahami pelajaran. Misalnya dalam mata kuliah bahasa Inggris Anak Usia Dini, dosen pengampu lebih memilih aplikasi WhatsApp sebagai media pembelajaran selama pembelajaran online berlangsung. Untuk metode pembelajaran dalam pembelajaran online menggunakan metode diskusi, metode kisah atau cerita menggunakan video, metode ceramah melalui voice note dan sebagainya. Mahasiswa dibimbing untuk mengenal berbagai cara pengajaran bahasa Inggris pada anak usia dini melalui berbagai video, gambar, cerita, kesenian dan lain-lain. Penggunaan aplikasi WhatsApp untuk pembelajaran online menjadi alternatif terbaik bagi Mahasiswa STAIN Sultan Abdurrahman Kepri dalam mengikuti perkuliahan.

\section{Kesimpulan}

Pembelajaran online yang dilakukan di STAIN Sultan Abdurrahman Kepri dipandang cukup membantu mahasiswa dalam memahami materi pelajaran terutama pada masa pandemi covid-19 saat ini. Pelaksanaan pembelajaran online menggunakan berbagai aplikasi yang mudah diinstal seperti whatsapp, google classroom, zoom dapat menjadi media pengganti tatap muka di kelas. Hal ini dilakukan untuk mendukung anjuran pemerintah dalam physical distancing dalam mencegah covid-19. Penggunaan berbagai aplikasi dalam pembelajaran online memberikan kemudahan kepada para mahasiswa dalam menerima pelajaran. Mahasiswa cukup login pada waktu yang telah ditentukan untuk sesi kelas online, mahasiswa juga dapat belajar dan berinteraksi dengan dosen dan sesama teman sekelas. Mahasiswa dapat menyelesaikan ujian, makalah, presentasi, kuis, dan tugas kelompok dalam 
format digital. Adapun masing-masing tugas tersebut diberikan oleh dosen dengan tenggang waktu yang harus dipatuhi oleh mahasiswa.

Berbagai aplikasi yang digunakan dalam pembelajaran online merupakan hal baru bagi mahasiswa dan dosen di STAIN Sultan Abdurrahman Kepri, sehingga pelaksanaannya juga masih belum maksimal. Mahasiswa masih lebih menyukai pembelajaran di dalam kelas karena bisa berinteraksi langsung dengan dosen terutama jika ada materi yang tidak dipahami. Berbeda dengan pembelajaran online, meskipun terkesan mudah dilakukan bagi mahasiswa karena akses yang cepat dan aplikasinya yang beragam seperti whatssap, google classroom, zoom dapat digunakan namun ternyata pembelajaran online masih berlum terlalu efektif bagi mahasiswa karena banyaknya kendala yang dihadapi mahasiswa seperti kesulitan jaringan, handphone yang tidak mendukung pembelajaran online, kuota internet yang tidak memadai untuk mengikuti pembelajaran online hingga keadaan cuaca yang berubah sewaktuwaktu mengingat kebanyakan mahasiswa STAIN Sultan Abdurrahman Kepri berasal dari berbagai pulau kecil di Kepulauan Riau. Kendati demikian, pembelajaran secara online yang dilakukan di masa pandemi covid-19 menjadi solusi alternatif terbaik untuk STAIN Sultan Abdurrahman Kepri dalam melaksanakan tridarma perguruan tinggi. Penelitian ini diharapkan dapat menjadi terobosan baru bagi STAIN Sultan Abdurrahman Kepri dalam melaksanakan pembelajaran online sehingga baik dosen maupun mahasiswa keduanya bisa sama-sama mengikuti proses kegiatan belajar mengajar dengan baik tentunya dengan meminimalisir kendala-kendala yang dihadapi mahasiswa.

\section{Ucapan Terimakasih}

Penulis mengucapkan terimakasih kepada mahasiswa STAIN Sultan Abdurrahman Kepri yang telah berpartisipasi dalam kegiatan penelitian serta kepada rekan-rekan pengajar di STAIN Sultan Abdurrahman Kepri yang telah memberikan bantuan dan dukungan kepada penulis demi kesuksesan penelitian ini.

\section{Referensi}

Udin S, Winataputra. (2007). Teori Belajar dan Pembelajaran. Jakarta: Universitas Terbuka. (Buku)

Aqib, Zainal. (2013). Model-model, Media, dan Strategi Pembelajaran Kontekstual (Inovatif). Bandung: Yrama Widya. (Buku)

Sutikno, M. Sobry. (2015). Metode dan Model-Model Pembelajaran, Menjadikan Proses Pembelajaran Lebih Variatif, Aktif, Inovatif, Efektif dan Menyenangkan. Mataram: Holistica. (Buku)

Kunto, Suharsimi Ari. (1990). Manajemen Penelitian. Jakarta: Rineka Cipta. (Buku)

Wiyani, Novan Ardy. (2013). Desain Pembelajaran Pendidikan: Tata Rancang Pembelajaran Menuju Pencapaian Kompetensi. Yogyakarta: Ar-Ruzz Media. (Buku) 
Indotrading News. Mengenal Zoom, Aplikasi Meeting Online Yang Menjadi Solusis Saat WFH. Diambil dari website https:// news.indotrading.com/mengenal-apa-itu-zoom-fitur-dan-cara-pemakaiannya/

Wikipedia. Apa itu WhatsApp?. Diambil dari website: https://id.wikipedia.org/wiki/WhatsApp

Wikipedia. Apa itu Google Clasroom?. Diambil dari website: https:/ /id.wikipedia.org/wiki/Google Kelas 